\title{
PENERAPAN SISTEM INFORMASI PENGELOLAAN KEUANGAN BERBASIS IT PADA IKATAN GURU RAUDHATUL ATHFAL SEMARANG UTARA
}

\author{
Lilis Setyowati", Zaky Machmuddah \\ Jurusan Akuntansi Fakultas Ekonomi dan Bisnis, Universitas Dian Nuswantoro \\ Jalan Nakula I, No. 5-11, Semarang 50131 \\ "Email: lilis.setyowati@dsn.dinus.ac.id
}

\begin{abstract}
Abstrak
Raudhatul Athfal merupakan (RA) merupakan lembaga pendidikan formal yang berada di bawah naungan Kementerian Agama yang menyelenggarakan pendidikan anak usia dini. Banyak lembaga pendidikan anak udia dini yang telah tumbuh berkembang tetapi masihi belum banyak yang menerapkan sistem informasi akuntansi dalam mengelola keuangan lembaganya. Tujuan dari kegiatan pengabdian kepada masyarakat ini untuk memberikan pengetahuan dan bekal kepada para guru serta staf administrasi yang tergabung dalam Ikatan Guru Raudhatul Athfal (IGRA) wilayah Semarang Utara mengenai pentingnya penerapan sistem informasi akuntansi pada lembaga pendidikan anak usia dini dalam mengelola keuagannya serta penyajian laporan keuangan yang berbasis pada teknologi informasi. Program kegiatan masyarakat ini dilakukan selama kurun waktu 3 bulan. Kegiatan pengabdian kepada masyarakat ini menggunakan metode pelatihan yang dilakukan di laboratorium komputer. Hasil kegiatan ini menunjukkan bahwa peserta sangat antusias dalam proses kegiatan dan melalui kegiatan ini peserta mampu mengelola keuangannya yang akuntabel berbasis teknologi informasi. Kegiatan ini juga memberikan dukungan yang penuh kepada sekolah Raudhatul Athfal dalam mewujudkan transparansi keuangan guna mewujudkan akuntabilitas publik.
\end{abstract}

Kata kunci: pengelolaan keuangan, sistem informasi, laporan keuangan, akuntabilitas

\section{PENDAHULUAN}

Pengelolaan keuangan merupakan salah satu gugusan substansi administrasi pendidikan. Pengelolaan keuangan ini bagian dari bidang garapan administrasi pendidikan yang secara khusus menanangi tugas-tugas yang berkaitan dengan pengelolaan keuangan yang dimiliki dan digunakan dalam lembaga pendidikan (Hayati, 2012). Pengelolaan keuangan di lembaga pendidikan anak usia dini dapat diartikan sebagai keseluruhan proses pemerolehan dan pendayagunaan uang secara tertib, efektif, efisien, dan dapat dipertanggungjawabkan dalam rangka memperlancar memperlancar pencapaian tujuan pendidikan. Ikatan Guru Raudhatul Athfal (IGRA) merupakan organisasi profesi yang beranggotakan guru-guru pada satuan pendidikan anak usia dini pada jalur pendidikan formal yang menyelenggarakan program pendidikan dengan kekhasan agama islam yang berada di bawah naungan departemen agama.

Manajemen keuangan yang dilakukan pada lembaga pendidikan bertujuan untuk mengatur berbagai hal yang berkaitan dengan masalah keuangan sehingga dana yang diperoleh dari berbagai sumber dapat dikelola dengan sebaik-baiknya (Hayati, 2012). Tujuan lainnya dilaksanakannya pengelolaan keuangan pada lembaga pendidikan untuk mengatur seluruh pemanfaatan dana yang tersedia Sari, 2017). Sumber dana di lembaga pendidikan tidak hanya bersumber dari yayasan yang menaunginya dan pemerintah saja, maka dari itu dana pendidikan yang tersedia harus dikelola secara efektif dan efisien. Semua yang berkaitan dengan pengelolaan keuangan hendaknya dikelola didasarkan pada standar keuangan yang berlaku sehingga dapat dipertanggungjawabkan kepada pihak yang berpekentingan. Mulyono (2010) mengemukakan beberapa kegiatan pengelolaan keuangan yang ada di lembaga pendidikan meliputi antara lain:

1. Perencanaan anggaran tahunan

2. Pengadaan anggaran

3. Pendistribusian anggaran

4. Pelaksanaan anggaran

5. Pembukuan anggaran

Di lain sisi, selain penerapannya pengelolaan keuangan yang baik, lembaga pendidikan juga 
hendaknya menerapkan administrasi yang memadai yaitu dengan mengeloladan mengarsip semua dokumen keuangan secara khusus sehingga dapat menjaga kelangsungan kegiatan yang berkaitan dengan pencapaian visi dan misi lembaga (Sari, 2017). Kenyataanya banyak lembaga pendidikan yang belum menerapkan pengelolaan keuangan dengan baik, yang dikarenakan keterbatasan sumber daya yang dimilikinya serta keterbatasan anggaran untuk mengadakan pelatihan dan perbaikan pengelolaan keuangan kepada pihak yang berkepentingan. Oleh sebab itu perlu diadakannya pelatihan dan pembenahan pengelolaan keuangan dan adminitrasi yang baik pada lembaga pendidikan.

Pengelolaan keuangan di lembaga Raudhatul Athfal (RA) bertujuan untuk mengatur sedemikian rupa sehingga semua upaya pemerolehan dana dari berbagai sumber dapat dilakukan dengan sebaik-baiknya. Jika hal ini dilakukan dengan sebaik-baiknya, semua upaya pemerolehan dana dapat berhasil. Raudhatul Athfal sebagai lembaga pendidikan anak usia dini, menerima Bantuan Operasional Pendidikan (BOP) dari Direktorat Jenderal Pendidikan Islam melalui Direktorak Kurikulum, Sarana, Kelembagaan dan Kesiswaan (KSKK) Madrasah. Adapun satuan BOP yang diterima oleh RA sebesar Rp 300.000 per siswa tiap tahun, dimana jumlah tersebut diterima dalam satu periode. Maka, bagi lembaga yang menerima dana dari pihak luar, maka akan dituntut untuk mempertanggungjawabkan atas penggunaan dananya tersebut kepada pihak yang terkait dalam bentuk laporan keuangan.

Lembaga yang menerima, menyimpan, dan membahas uang negara diwajibkan untuk mencatatnya secara tertib (Dirjen Pendidikan Islam, 2019). Pedoman yang digunakan yaitu dari Keputusan Direktur Jenderal Pendidikan Islam Nomor 632 tahun 2019 tentang Petunjuk Teknis BOP RA. RA yang sebagai penerima uang dari berbagai sumber, maka harus mampu untuk mengelola keuangannya secara akuntabel dan transparan. Sebagai salah satu bentuk pertanggungjawaban dalam pelaksanaan program BOP RA, masing-masing pengelola RA dituntut untuk melaporkan hasil kegiatan dan penggunaan dananya kepada pihak terkait. Penerimaan RA selain dana BOP dari pemerintah RA juga mendapat pemasukan yang berasal dari para murid yang berupa uang gedung, SPP, dan uang tabungan masih membutuhkan sistem pengelolaan yang akuntabel dan transparan.

Kondisi di Semarang saat ini menunjukkan bahwa anggota Ikatan Guru Raudhatul Athfal terdiri dari 134 lembaga RA dengan 625 guru dan 11.000 murid. Kondisi kenyataannya menunjukkan bahwa hampir seluruh RA di Semarang ini merangkap pekerjaan guru sekaligus merangkap sebagai tenaga administrasi dan keuangan, sehingga para guru RA dituntut untuk mampu mengelola keuangannya secara akuntabel dan transparan hingga menyajikannya dalam bentuk laporan keuangan. Dengan demikian para guru RA yang berlatar belakang pendidikan non akuntansi harus mampu mengelola keuangan hingga pelaporan, sehingga para guru RA membutuhkan pelatihan pengelolaan keuangan yang terkomputerisasi untuk memudahkan dalam menyusun laporan keuangannya.

Tujuan diselenggarakannya kegiatan ini yaitu untuk meningkatkan pengetahuan dan kompetensi yang dimiliki oleh guru-guru Raudhatul Athfal mengenai proses penyusunan laporan pertanggungjawaban penggunaan dana BOP yang akuntabel dan berbasis sistem informasi.

\section{METODE}

Metode yang digunakan dalam menyelesaikan masalah ini yaitu sebagai berikut:

1. Metode konsolidasi dengan ketua Ikatan Guru Raudhatul Athfal mengenai kebutuhan yang diperlukan bagi para guru atau tenaga administrasi dalam proses pengelolaan keuangan

2. Pelaksanaan kegiatan pengabdian kepada masyarakat dengan memberikan pelatihan kepada para guru dan tenaga administrasi keuangan

3. Materi yang diperoleh peserta berupa tentang hal-hal sebagai berikut:

a. pentingnya pengelolaan keuangan lembaga

b. pengenalan Microsoft Office Excel

c. pencatatan transaksi keuangan kedalam sistem informasi berbasis excel

d. cara mengelola keuangan secara efektif dan efisien

e. monitoring dan evaluasi terhadap kegiatan yang telah dilakukan 


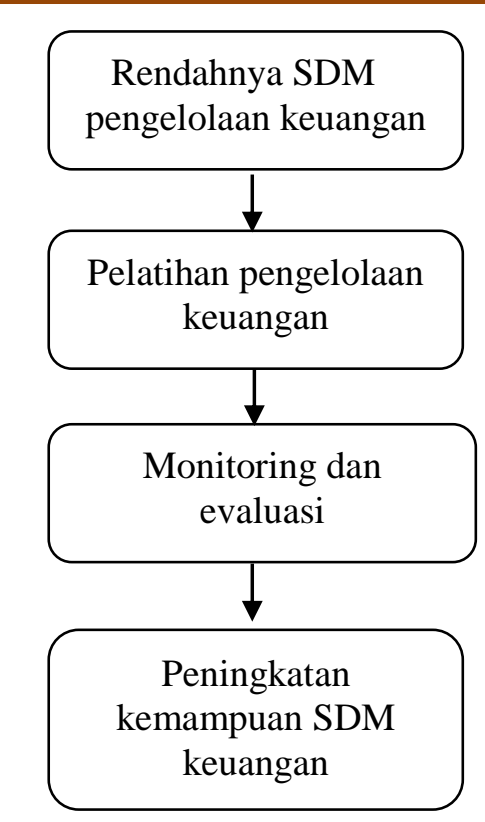

Gambar 1. Kerangka pemikiran

\section{HASIL DAN PEMBAHASAN}

Kegiatan pengabdian kepada masyarakat ini dilakukan di laboratoriun computer Universitas Dian Nuswantoro dengan peserta para tenaga kependidikan dan staf administrasi di lembaga anak usia dini yang tergabung dalam Ikatan Guru Raudhatul Athfal (IGRA) di wilayah Semarang Utara. Lembaga ini merupakan lembaga pendidikan pra sekolah yang akan menyipakan putra putri Indonesia yang cedas dan beriman serta mengembangkan kemampuan dasar. IGRA yang berasaskan Islam memiliki peran sebagai pendorong dan pembaharuan dengan menyelenggarakan usaha dan kegiatan yang menunjang pelaksanaan proses belajar mengajar, menampung dan menyalurkan aspirasi anggota dan menyelenggarakan usaha dan kegiatan untuk meningkatkan dan memelihara kesejahteraan anggota. Adapun visi dan misi IGRA sebagai berikut:

Visi:

"Kreatif, inovatif, islami"

Misi:

1. Meningkatkan kualitas profesionalisme kepala dan guru Raudhatul Athfal

2. Menjalin ukhwah islamiyah

3. Menghantarkan generasi yang islami

4. Membantu mengembangkan seluruh potensi anak

Tujuan:

1. Menyamakan visi, misi dan persepsi Raudhatul Athfal

2. Memelihara dan mempererat tali silaturahmi antara kepala dan guru

3. Memelihara dan meningkatkan wawasan serta meningkatkan aktivitas dedikasi dan kepala dan guru

Kegiatan pelatihan dan bimbingan mengenai pengelolaan keuangan yang baik sesuai dengan kebutuhan pengguna dan berdasarkan standard keuangan yang berlaku. Pelatihan ini dirancang secara khusus agar mudah dipahami oleh pengguna. Pemberian ilmu terkait dengan pengelolaan keuangan serta diberikan aplikasi dan simulasi terkait dengan pengelolaan keuangan yang dibutuhkan oleh yayasan. Tujuannya yaitu supaya pengurus dapat menerapkan pengelolaan yang baik dan layak serta memadahi sehingga proses pengelolaan keuangan dapat berjalan dengan baik dan dapat dipertanggungjawabkan kepada yang berkepentingan.

Proedur yang dilakukan pada kegiatan pengabdian kepada masyarakat ini meliputi:

1. Sebelum kegiatan pelatihan ini dilakukan, jadwal pelatihan ditentukan dengan melakukan konfirmasi waktu terlebih dahulu kepada mitra, serta tim pelaksana akan menyiapkan materi 
dan handout agar para peserta pelatihan cepat dalam memahami materi yang diberikan

2. Kegiatan pendampingan bertujuan untuk membantu lembaga pendidikan dalam memahami dan menjalankan pengelolaan keuangan yang baik

3. Kegiatan evaluasi dilakukan secara langsung pada saat simulasi selama kegiatan berlangsung. Tujuannya untuk memperbaiki pelaksanaan berikutnya dan seandainya ada hambatan, maka akan didiskusikan dengan mitra untuk mencarikan solusi dan pemecahannya, sehingga kedepannya diharapkan akan terjalin kerja sama antra mitra dengan Universitas Dian Nuswantoro khususnya Program Studi Akuntansi Fakultas Ekomoni dan Bisnis dengan bersama-sama mencerdaskan anak bangsa dan mempunyai akhlak yang mulia.

Bentuk partisipasi mitra dalam kegiatan pengabdian kepada masyarakat ini antara lain:

1. Menyediakan waktu untuk kegiatan pelatihan ini

2. Memberikan dukungan, pengawasan dan pembinaan selama kegiatan pengabdian kepada masyarakat kepada peserta yang ditunjuk untuk mewaliki lembaganya

Program kegiatan pengabdian kepada masyarakat ini telah selesai dan berhasil dengan pencapaian sebagai berikut:

1. Terselenggaranya program pengabdian pelatihan pengelolaan keuangan lembaga

2. Para guru dan tenaga administrasi keuangan mampu mengelola keuangan lembaga berbasis teknologi informasi

3. Terwujudnya penerapan pengelolaan keuangan berbasis teknologi informasi di lembaga

Dengan terselenggaranya kegiatan pengabdian kepada masyarakat ini para guru serta tenaga administasi keuangan mampu mengelola sistem informasi keuangan serta mampu meningkatkan kualitas sumber daya manusia dalam mengelola keuangan lembaga yang berbasis teknologi informasi serta menyajikannya dalam bentuk laporan keuangan yang akuntabel. Kegiatan penerapan sistem informasi pengelolaan keuangan berbasis teknologi informasi ini telah berjalan dengan sukses. Adapun kegiatan ini telah dilakukan pada:

$\begin{array}{ll}\text { Hari/tanggal } & \text { : Kamis, 9 Januari 2020 } \\ \text { Alamat } & \text { : Jl. Nakula I No 5-11 Semarang } \\ \text { Tempat } & \text { : Laboratorium komputer } \\ \text { Peserta } & : \text { 35 peserta yang terdiri dari Guru dan staf administrasi keuangan IGRA } \\ & \text { Semarang Utara } \\ \text { Pemateri } & \text { : Lilis Setyowati, SE., M.Si., Ak., CA } \\ & \text { dan Zaky Machmuddah, SE., M.Si., Akt., CA., CSRA }\end{array}$

Kegiatan ini dilakukan dengan tahapan memberikan pengenalan Microsoft office excel kemudian mencoba membuat sistem sederhana yang berbasis pada Microsoft excel, serta memberikan aplikasi sistem akuntansi sederhana dengan Microsoft excel dan memberikan pelatihan pengoperasionalan aplikasi tersebut, sehingga dengan pemanfaatan aplikasi akuntansi tersebut dapat membantu tata kelola keuangan di masing-masing lembaga. Adapun susunan materi dalam pelatihan ini sebagai berikut:

Tabel 1. Materi Pengabdian

\begin{tabular}{ccl}
\hline No & Materi & \multicolumn{1}{c}{ Rincian } \\
\hline 1 & Materi 1 & Peran teknologi dalam organisasi \\
\hline 2 & Materi 2 & Proses pengelolaan keuangan yang baik \\
\hline 3 & Materi 3 & Pengenalan Microsoft office Excel \\
\hline 4 & Materi 4 & Penerapan Sistem Informasi keuangan \\
\hline
\end{tabular}



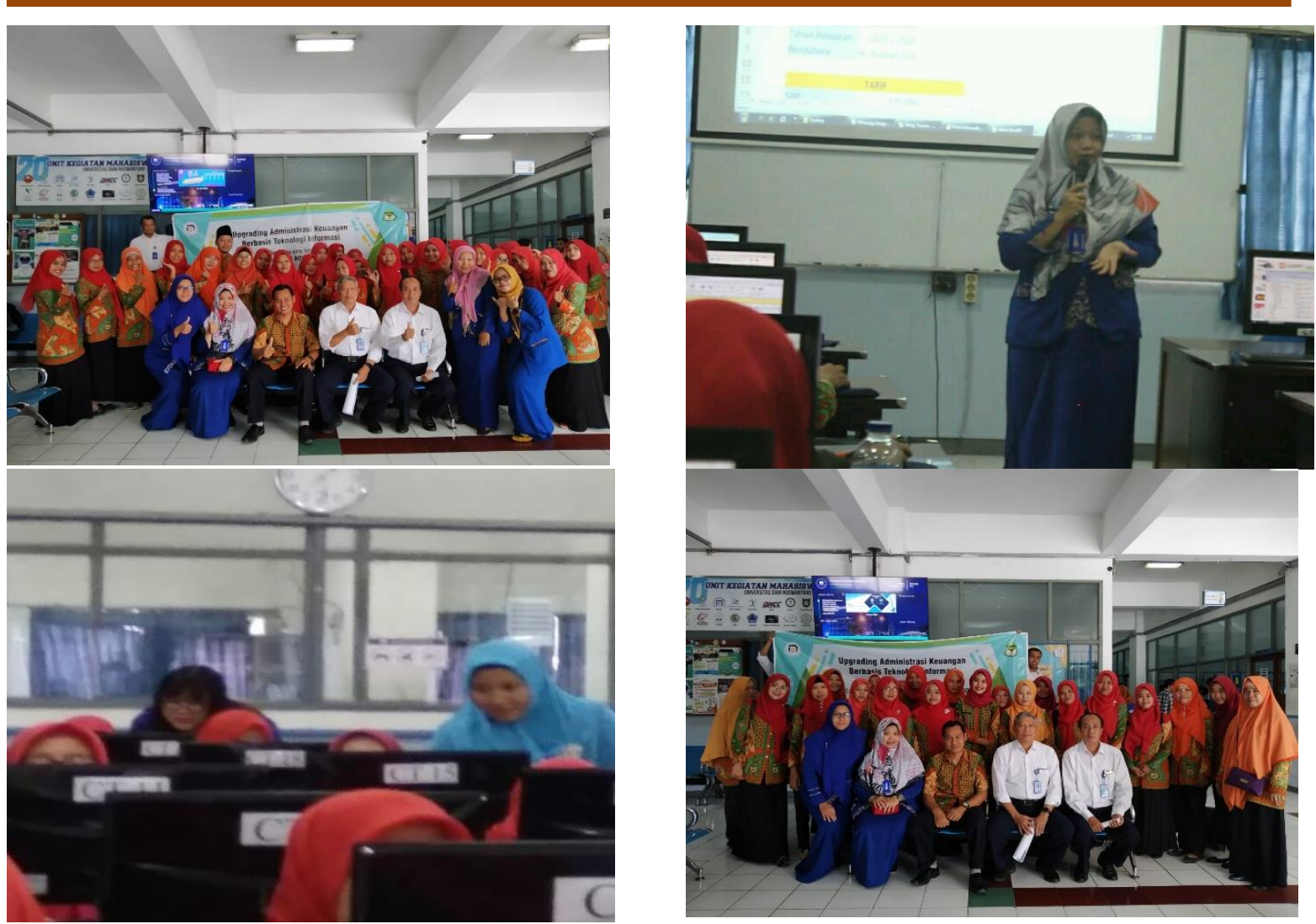

Gambar 2. Foto kegiatan pemberian pelatihan

\section{KESIMPULAN}

Berdasarkan kegiatan pengabdian kepada masyarakat yang telah dilaksanakan dengan peserta para Guru dan tenaga administrasi keuangan yang tergabung dalam Ikatan Guru Raudhatul Athfal di wilayah Semarang Utara, maka dapat disimpulkan bahwa kegiatan telah berjalan dengan baik dan lancar serta peserta mendapat ilmu baru mengenai pengelolaan keuangan di lembaga dan para peserta mendapatkan aplikasi sistem akuntansi yang bisa diterapkan di lembaga masingmasing. Selanjutnya diharapkan setelah masing-masing menerapkan aplikasi sistem informasi tersebut diharapkan mampu mengelola keuangan yang transpatan, efektif dan efisien serta menyajikannya dalam laporan keuangan yang akuntabel.

Rencana tahapan selanjutnya yaitu masih diperlukannya pendampingan mengenai pengaplikasian sistem informasi akuntansi di tiap lembaga sehingga tercipta pengelolaan keuangan yang akuntabel dan akhirnya akan memberikan dapmpak yang positif kepada lembaga dalam meningkatkan akuntabilitas dan transparansi pengelolaan keuangan di masing-masing lembaga.

\section{DAFTAR PUSTAKA}

Hayati, E.D. 2012. Manajemen Pembiayaan Berbasis Sekolah di RSBI SMPN 3 Mranggen Demak. Educational Management Journal. Vo.1 No.2

Keputusan Direktur Jenderal Pendidikan Islam Nomor 632. 2019. Petunjuk Teknis Bantuan Operasional Pendidikan Raudhatul Athfal Tahun Anggaran 2019

Mulyono. 2010. Konsep Pembiayaan Pendidikan. Yogyakarta. Ar-Ruzz

Sari, Andika Puspita. 2017. Pengelolaan Keuangan Sekolah dan Upaya Perbaikan Sistem Manajemen Keuangan di TK Gaya Baru III Jebres 